\title{
Analisis KI-3 Kurikulum 2013 Kimia pada Kelas X SMA
}

\section{An KI-3 Analysis of Curriculum 2013 on Chemistry Subject at $1^{\text {st }}$ Grade of Senior High School}

\author{
Y Andayani $^{1}$ and E Yusmaita ${ }^{*}$ \\ ${ }^{1}$ Pendidikan Kimia, Universitas Negeri Padang, Jl. Prof. Dr. Hamka, Air Tawar Barat, \\ Padang Utara, Sumatera Barat, Indonesia 25171 \\ *ekayusmaita@fmipa.unp.ac.id
}

ARTICLE INFO

Received 14 October 2019

Revised 20 October 2019

Published 21 October 2019

\begin{abstract}
The content standard has several components, including the level of competence, core competency (KI), basic competency (KD) and the scope of the material. The content standard always changes according to the needs of curriculum to be applied. The purpose of this research is to analyze the formula of KI-3 based on Bloom taxonomic revision. This is one of the basic frameworks in curriculum preparation which starts from the cognitive and knowledge dimensions. The type of this research is descriptive qualitative. Data collection techniques is using library research. The data source used Permendikbud No. 37 of 2018. The formula KI-3 was analyzed based on knowledge activities, types of knowledge and scientific attitudes. The results of KI-3 formulation at $1^{\text {st }}$ grade of senior high school obtained 36 components of KI-3.
\end{abstract}

\section{KEYWORDS}

Standard Content, Curriculum, Curriculum 2013, Analysis, Bloom taxonomic revision

\begin{abstract}
ABSTRAK
Standar isi memiliki beberapa komponen, diantaranya tingkat kompetensi, kompetensi inti (KI), kompetensi dasar (KD) serta ruang lingkup materi. Standar isi selalu mengalami perubahan sesuai dengan kebutuhan kurikulum yang akan diterapkan. Tujuan dari penelitian ini adalah untuk menganalisis rumusan KI-3 berdasarkan taksonomi bloom revisi. Taksonomi bloom revisi merupakan salah satu kerangka dasar dalam penyusunan kurikulum yang dimulai dari dimensi kognitif dan dimensi pengetahuan. Jenis penelitian ini menggunakan teknik pengumpulan data library research. Sumber data yang digunakan adalah Permendikbud No. 37 Tahun 2018. Rumusan KI-3 dianalisis berdasarkan aktivitas pengetahuan, jenis pengetahuan dan sikap ilmiah. Hasil rumusan KI-3 kelas X SMA didapatkan sebanyak 36 komponen KI-3.
\end{abstract}

KATA KUNCI

Standar Isi, Kurikulum, Kurikulum 2013, Analisis, Taksonomi Bloom Revisi 


\section{PENDAHULUAN}

Standar nasional pendidikan merupakan kriteria minimal tentang sistem pendidikan diseluruh wilayah hukum Negara Kesatuan Republik Indonesia. Standar nasional pendidikan memiliki 8 standar, diantaranya: 1) standar kompetensi lulusan; 2) standar isi; 3) standar proses; 4) standar pendidikan dan tenaga kependidikan; 5) standar sarana dan prasarana; 6) standar pengelolaan; 7) standar pembiayaan pendidikan; 8) standar penilaian pendidikan. Dua dari delapan standar nasional pendidikan tersebut yaitu standar isi dan standar kompetensi lulusan merupakan acuan utama bagi satuan pendidikan dalam mengembangkan kurikulum $^{[1]}$. Kurikulum merupakan seperangkat rencana dan pengaturan mengenai tujuan, isi dan bahan pelajaran serta bahan yang digunakan sebagai pedoman penyelenggaraan kegiatan belajar untuk mencapai tujuan pendidikan tertentu ${ }^{[2]}$. Kurikulum yang dipakai saat ini adalah kurikulum 2013.

Standar kompetensi lulusan adalah kriteria mengenai kualifikasi kemampuan lulusan yang mencakup sikap, pengetahuan dan keterampilan ${ }^{[3]}$. Standar isi merupakan kriteria mengenai ruang lingkup materi dan tingkat kompetensi peserta didik untuk mencapai kompetensi lulusan pada jenjang dan jenis pendidikan tertentu. Standar isi dikembangkan untuk menentukan kriteria ruang lingkup dan tingkat kompetensi yang sesuai dengan kompetensi lulusan yang dirumuskan pada standar kompetensi lulusan, yaitu sikap, pengetahuan dan keterampilan $^{[4]}$. Standar isi memiliki beberapa komponen, diantaranya: tingkat kompetensi, kompetensi inti (KI), kompetensi dasar (KD) serta ruang lingkup materi. Standar isi selalu mengalami perubahan sesuai dengan kebutuhan kurikulum yang akan diterapkan. Perubahan itu disebabkan oleh kurikulum pendidikan di Indonesia mengalami pembaharuan.

Kompetensi adalah pengetahuan, keterampilan, kemampuan atau karakteristik yang berhubungan dengan tingkat kemampuan kerja dalam penyelesaian masalah, pemikiran kritis atau kepemimpinan ${ }^{[4]}$. Tingkat kompetensi dirumuskan berdasarkan kriteria tingkat perkembangan peserta didik, kualifikasi kompetensi Indonesia dan penguasaan kompetensi yang berjenjang.

Kompetensi inti sekolah menengah atas/ madrasah aliyah (SMA/MA) merupakan tingkat kemampuan untuk mencapai standar kompetensi lulusan (SKL) yang harus dimiliki oleh seorang peserta didik SMA/MA pada setiap tingkat kelas. Kompetensi inti ini dirancang untuk setiap kelas. Rumusan kompetensi inti menggunakan notasi sebagai berikut: 1) kompetensi inti-1 (KI-1) untuk kompetensi inti sikap spiritual; 2) kompetensi inti-2 (KI-2) untuk kompetensi inti sikap sosial; 3) kompetensi inti3 (KI-3) untuk kompetensi inti pengetahuan dan 4) kompetensi inti-4 (KI-4) untuk kompetensi inti keterampilan $^{[5]}$. Pada penelitian ini kompetensi inti yang dianalisis adalah kompetensi inti 3.
Taksonomi bertujuan untuk mengelompokkan tujuan pembelajaran, pengajaran, dan sasaran belajar yang digolongkan dalam tiga ranah (domain), yaitu (1) ranah kognitif berkaitan dengan kemampuan berpikir, (2) ranah afektif berkaitan dengan sikap dan perilaku (emosi dan perasaan), (3) ranah psikomotorik berkaitan dengan penggunaan otot kerangka atau keterampilan motorik ${ }^{[6]}$. Analisis kompetensi inti 3 dilakukan berdasarkan taksonomi Bloom revisi.

Taksonomi Bloom revisi melakukan pemisahan yang tegas antara dimensi pengetahuan dan dimensi kognitif karena dimensi kognitif merupakan kata kerja sedangkan dimensi pengetahuan merupakan kata benda.

Dimensi proses kognitif terdiri dari enam level: remembering (mengingat), understanding (memahami), applying (menerapkan), analyzing (menganalisis, mengurai), evaluating (menilai), dan creating (mencipta), selanjutnya untuk dimensi pengetahuan terdiri dari faktual, konseptual, prosedural dan metakognitif ${ }^{7]}$.

Tingkat kompetensi yang berbeda akan menuntut pembelajaran dan penilaian dengan penekanan dan fokus yang berbeda pula. Semakin tinggi tingkat kompetensi maka semakin kompleks pula intensitas proses Pembelajaran dan pengalaman belajar serta penilaian ${ }^{[8]}$. Oleh karena itu, perlu dilakukan suatu analisis pada KI-3 untuk melihat tingkatan dimensi proses kognitif dan dimensi pengetahuan yang harus dicapai oleh peserta didik berdasarkan taksonomi Bloom revisi. Dimana analisis ini adalah kegiatan menguraikan material menjadi bagian-bagian penyusunnya dan menentukan bagimana bagian-bagian tersebut saling terkait satu sama lain dengan keseluruhan struktur dan tujuan ${ }^{[9]}$. Pada penelitian ini bagian yang dianalisis adalah KI-3 pada kelas X yang di uraikan menjadi bagian-bagian penyusunnya (dimensi proses kognitif; ranah pengetahuan dan sikap ilmiah)

\section{METODE}

Teknik pengumpulan data menggunakan library research. Sumber data pada penelitian ini adalah Permendikbud Nomor 37 Tahun 2018 tentang Perubahan Kompetensi Inti dan Kompetensi Dasar, Permendikbud Nomor 21 Tahun 2016 Tentang Standar Isi Pendidikan Dasar dan Menengah, dan taksonomi Bloom revisi. Data yang dijelaskan pada penelitian ini adalah hasil analisis KI-3 berdasarkan taksonomi Bloom revisi yang dibatasi pada kurikulum 2013 revisi 2018 kelas satu SMA.

\section{HASIL DAN DISKUSI}

\subsection{Taksonomi Bloom Revisi}

Taksonomi Bloom revisi terdiri dari dimensi kognitif dan dimensi pengetahuan. Tuntutan dimensi kognitif yang terdapat pada kelas satu SMA adalah Memahami (C2); Menerapkan (C3); dan menganalisis (C4). 
Analisis KI-3 kurikulum 2013 pada kelas satu SMA, peserta didik dituntut mampu menguasai dimensi kognitif sampai pada level menganalisis (C4) dan menguasai dimensi pengetahuan sampai pada tahap prosedural. Selain dimensi proses kognitif dan dimensi pengetahuan, rumusan KI-3 juga dijabarkan berdasarkan lampiran dari Permendikbud No. 21 Tahun 2016 tentang standar isi pendidikan dasar dan menengah. Sikap ilmiah yang terdapat pada KI-3 yaitu rasa ingin tahu.

\subsection{Hasil Analisis Kompetensi Inti}

Rumusan KI-3yangakan dianalisis: Memahami, menerapkan dan menganalisis pengetahuan faktual, konseptual, prosedural berdasarkan rasa ingin tahunya tentang ilmu pengetahuan, teknologi, seni, budaya, dan humaniora dengan wawasan kemanusiaan, kebangsaan, kenegaraan dan peradaban terkait penyebab fenomena dan kejadian, serta menerapkan pengetahuan prosedural pada bidang kajian yang spesifik sesuai dengan bakat dan minatnya untuk memecahkan masalah.

Hasil analisis rumusan kompetensi inti menujukkan hasil seperti dalam Tabel 1 .

\subsection{Pembahasan}

Analisis KI-3 dilakukan dengan menguraikan, mengorganisir dan menemukan pesan tersirat dari dimensi proses kognitif dan dimensi pengetahuan berdasarkan taksonomi Bloom revisi.Rumusan KI-3 diperoleh dari permendikbud nomor 37 tahun 2018 dibatasi pada KI-3 kelas X SMA.

Pada penelitian ini rumusan KI yang dianalisis yaitu: KI-3: Memahami, menerapkan dan menganalisis pengetahuan faktual, konseptual, prosedural berdasarkan rasa ingin tahunya tentang ilmu pengetahuan, teknologi, seni, budaya dan humaniora dengan wawasan kemanusiaan, kebangsaan, kenegaraan dan peradaban terkait penyebab fenomena dan kejadian, serta menerapkan pengetahuan prosedural pada bidang kajian yang spesifik sesuai dengan bakat dan minatnya untuk memecahkan masalah ${ }^{[10]}$.

KI-3 dianalisis berdasarkan taksonomi Bloom revisi serta rumusan KI-3 ini dikelompokkan sesuai dengan dimensi proses kognitif, dimensi pengetahuan dan sikap ilmiah sehingga akan diperoleh komponen KI-3.

Rumusan KI-3 mencakup dimensi proses kognitif yaitu memahami (C2), menerapkan (C3) dan menganalisis (C4), dimensi proses kognitif untuk kelas X dibatasi pada level C-4. Dimensi proses kognitif memahami (C2) dibagi menjadi tujuh bagian yaitu, 1) menafsirkan; 2) memberi contoh; 3) mengklasifikasikan; 4) meringkas; 5) menarik inferensi; 6) membandingkan; dan 7) menjelaskan, selanjutnya dimensi proses kognitif menerapkan (C3) dibagi menjadi dua macam yaitu, 1) menjalankan; 2) mengimplementasikan, dan dimensi proses kognitif menganalisis (C4) dibagi menjadi 3 macam yaitu, 1) menguraikan; 2) mengorganisir; 3) menemukan pesan tersirat.

Dimensi pengetahuan untuk rumusan
KI-3 pada kelas satu menuntut 3 jenis dimensi pengetahuan yaitu: 1) faktual; 2) konseptual; 3) prosedural. Pengetahuan faktual dibagi menjadi 2 yaitu: 1) pengetahuan tentang terminology; 2) pengetahuan tentang bagian detail dan unsurunsur. Pengetahuan konseptual mencakup skema. Dan model pemikiran dan teori baik yang implisit dan ekplisit.Pengetahuan konseptual terdiri dari tiga macam yaitu, 1) pengetahuan tentang klasifikasi dan kategori; 2) pengetahuan tentang prinsip dan generalisasi; 3) pengetahuan tentang teori, model dan struktur. Pengetahuan prosedural pengetahuan tentang bagimana mengerjakan sesuatu yang bersifat rutin maupun yang baru . Pengetahuan prosedural ini berisi langkah-langkah atau tahapan yang harus diikuti dalam mengerjakan sesuatu yang baru. Pengetahuan prosedural dibagi menjadi 3 macam, yaitu: 1) pengetahuan tentang keterampilan khusus yang berhubungan dengan suatu bidang tertentu dan pengetahuan tentang algoritma; 2) pengetahuan tentang teknik dan metode yang berhubungan dengan suatu bidang tertentu; 3) pengetahuan tentang kriteria untuk menemukan kapan suatu prosedur tepat untuk digunakan. Kemudian, sikap ilmiah yang terdapat pada rumusan KI-3 ini adalah rasa ingin tahu.

Pada tahapan analisis KI-3 dilakukan dengan mencocokkan dan menjelaskan dimensi proses kognitif dan dimensi pengetahuan dengan mengacu pada taksonomi Bloom revisi.

Berdasarkan tabel 2 maka didapatkan komponen KI-3 pada kelas X menghasilkan 36 komponen KI-3. Komponen KI yang didapatkan telah analisis berdasarkan dimensi proses kognitif dan dimensi pengetahuan. Dimensi pengetahuan yang dipelajari dikelas $\mathrm{X}$ yaitu pengetahuan faktual, konseptual dan prosedural. Untuk masing-masing dimensi kognitif dianalisis sesuai dengan dimensi pengetahuan. Sehingga didapatkan 3 komponen kompetensi inti 3 untuk masing-masing dimensi proses kognitif pada kelas X.

Berdasarkan rumusan KI pada kurikulum 2013, komponen KI selanjutnya dibatasi pada ilmu pengetahuan, maka didapatkan komponen KI pada kurikulum yaitu:

"Menafsirkan pengetahuan faktualberdasarkan rasa ingin tahunya tentang ilmu pengetahuan, teknologi, seni, budaya, dan humaniora dengan wawasan kemanusiaan, kebangsaan, dan peradaban terkait penyebab fenomena dan kejadian, serta menerapkan pengetahuan prosedural pada bidang kajian yang spesifik sesuai dengan bakat dan minatnya untuk memecahkan masalah (C2)".

"Menafsirkan pengetahuan konseptual berdasarkan rasa ingin tahunya tentang ilmu penegtahuan, teknologi, seni, budaya, dan humaniora dengan wawasan kemanusiaan, kebangsaan, kenegaraan, dan peradaban terkait penyebab fenomena dan kejadian, serta menerapkan pengetahuan prosedural pada bidang kajian yang spesifik sesuai dengan bakat dan minatnya untuk memecahkan masalah (C2)". 
Tabel 1. Hasil Analisis Kompetensi Inti 3 yang disederhanakan

\section{Rumusan KI 3 :}

Memahami, menerapkan dan menganalisis pengetahuan faktual, konseptual, prosedural berdasarkan rasa ingin tahunya tentang ilmu pengetahuan, teknologi, seni, budaya, dan humaniora dengan wawasan kemanusiaan, kebangsaan, kenegaraan dan peradaban terkait penyebab fenomena dan kejadian, serta menerapkan pengetahuan prosedural pada bidang kajian yang spesifik sesuai dengan bakat dan minatnya untuk memecahkan masalah (Permendikbud No. 37 Tahun 2018)

\begin{tabular}{|c|c|c|c|c|}
\hline \multicolumn{2}{|c|}{$\begin{array}{l}\text { Dimensi Proses } \\
\text { Kognitif }\end{array}$} & Dimensi Pengetahuan & Sikap Ilmiah & $\begin{array}{c}\text { Komponen } \\
\text { KI } 3\end{array}$ \\
\hline \multirow{7}{*}{$\begin{array}{l}\text { Mema- } \\
\text { hami (C2) }\end{array}$} & Menafsirkan & \multirow{12}{*}{$\begin{array}{l}\text { 1. Faktual } \\
\text { - } \quad \text { Pengetahuan tentang terminologi } \\
\text { - } \text { Pengetahuan tentang bagian de- } \\
\text { tail dan unsur-unsur } \\
\text { 2. Konseptual } \\
\text { - } \quad \text { Pengetahuan tentang klasifikasi } \\
\text { dan kategori } \\
\text { - } \text { Pengetahuan tentang prinsip dan } \\
\text { generalisasi } \\
\text { - Pengetahuan tentang teori, model, } \\
\text { dan struktur } \\
\text { Prosedural } \\
\text { Pengetahuan tentang keterampi- } \\
\text { lan khusus dengan suatu bidang } \\
\text { tertentu dan pengetahuan tentang } \\
\text { algoritme } \\
\text { Pengetahuan tentang teknik dan } \\
\text { metode yang berhubungan dengan } \\
\text { suatu bidang tertentu } \\
\text { Pengetahuan tentang kriteria } \\
\text { untuk menentukan kapan suatu } \\
\text { prosedur tepat untuk digunakan } \\
\text { (Widodo, 2006; Krathwohl, 2001) }\end{array}$} & \multirow{12}{*}{$\begin{array}{l}\text { Rasa ingin } \\
\text { tahu (Per- } \\
\text { mendikbud } \\
\text { Nomor } 21 \\
\text { Tahun 2016) }\end{array}$} & 3 komponen KI \\
\hline & $\begin{array}{l}\text { Memberi } \\
\text { contoh }\end{array}$ & & & 3 komponen $\mathrm{KI}$ \\
\hline & $\begin{array}{l}\text { Mengklasi- } \\
\text { fikasikan }\end{array}$ & & & 3 komponen $\mathrm{KI}$ \\
\hline & Meringkas & & & 3 komponen KI \\
\hline & $\begin{array}{l}\text { Menarik } \\
\text { inferensi }\end{array}$ & & & 3 komponen $\mathrm{KI}$ \\
\hline & $\begin{array}{l}\text { Memband- } \\
\text { ingkan }\end{array}$ & & & 3 komponen KI \\
\hline & $\begin{array}{c}\text { Menjelas- } \\
\text { kan }\end{array}$ & & & 3 komponen KI \\
\hline \multirow{5}{*}{$\begin{array}{c}\text { Mengana- } \\
\text { lisis (C4) } \\
\text { (Widodo, } \\
\text { 2006; } \\
\text { Krath- } \\
\text { wohl, } \\
\text { 2001) }\end{array}$} & $\begin{array}{c}\text { Menjalan- } \\
\text { kan }\end{array}$ & & & 3 komponen KI \\
\hline & $\begin{array}{l}\text { Mengimpe- } \\
\text { lementasi- } \\
\text { kan } \\
\end{array}$ & & & 3 komponen $\mathrm{KI}$ \\
\hline & $\begin{array}{l}\text { Mengurai- } \\
\text { kan }\end{array}$ & & & 3 komponen KI \\
\hline & $\begin{array}{l}\text { Mengorgan- } \\
\text { isir } \\
\end{array}$ & & & 3 komponen $\mathrm{KI}$ \\
\hline & $\begin{array}{l}\text { Menemukan } \\
\text { pesan ter- } \\
\text { sirat (Wido- } \\
\text { do, 2006; } \\
\text { Krathwohl, } \\
\text { 2001) }\end{array}$ & & & 3 komponen KI \\
\hline
\end{tabular}

Contoh komponen KI:

1. Menafsirkan pengetahuan faktual berdasarkan rasa ingin tahunya tentang ilmu pengetahuan, teknologi, seni, budaya, dan humaniora dengan wawasan kemanusiaan, kebangsaan, kenegaraan, dan peradaban terkait penyebab fenomena dan kejadian, serta menerapkan pengetahuan prosedural pada bidang kajian yang spesifik sesuai dengan bakat dan minatnya untuk memecahkan masalah.

2. Menafsirkan pengetahuan konseptual berdasarkan rasa ingin tahunya tentang ilmu penegtahuan, teknologi, seni, budaya, dan humaniora dengan wawasan kemanusiaan, kebangsaan, kenegaraan, dan peradaban terkait penyebab fenomena dan kejadian, serta menerapkan pengetahuan prosedural pada bidang kajian yang spesifik sesuai dengan bakat dan minatnya untuk memecahkan masalah.

3. Menafsirkan pengetahuan prosedural berdasarkan rasa ingin tahunya tentang ilmu pengetahuan, teknologi, seni, budaya, dan humaniora dengan wawasan kemanusiaan, kebangsaan, kenegaraan, dan peradaban terkait penyebab fenomena dan kejadian, serta menerapkan pengetahuan prosedural pada bidang kajian yang spesifik sesuai dengan bakat dan minatnya untuk memecahkan masalah.

"Menafsirkan pengetahuan prosedural berdasarkan rasa ingin tahunya tentang ilmu pengetahuan, teknologi, seni, budaya, dan humaniora dengan wawasan kemanusiaan, kebangsaan, kenegaraan, dan peradaban terkait penyebab fenomena dan kejadian, serta menerapkan pengetahuan prosedural pada bidang kajian yang spesifik sesuai dengan bakat dan minatnya untuk memecahkan masalah (C2)”.

Kalimat pada bagian rumusan KI-3 “ilmu pengetahuan, teknologi, seni, budaya dan humaniora dengan wawasan kemanusiaan, kebangsaan, kenegaraan, dan peradaban terkait penyebab fenomena dan kejadian" tidak diuraikan lagi karena kalimat tersebut sebagai kalimat pelengkap pada rumusan KI-3. Rumusan KI-3 yang telah disederhanakan dapat dilihat pada contoh dibawah ini:

"Menafsirkan pengetahuanfaktual berdasarkan rasa ingin tahunya tentang ilmu pengetahuan 
terkait penyebab fenomena dan kejadian, serta menerapkan pengetahuan prosedural pada bidang kajian yang spesifik sesuai dengan bakat dan minatnya untuk memecahkan masalah (C2)."

"Menafsirkan pengetahuan konseptual berdasarkan rasa ingin tahunya tentang ilmu pengetahuan terkait penyebab fenomena dan kejadian, serta menerapkan pengetahuan prosedural pada bidang kajian yang spesifik sesuai dengan bakat dan minatnya untuk memecahkan masalah (C2)."

"Menafsirkan pengetahuan prosedural berdasarkan rasa ingin tahunya tentang ilmu pengetahuan terkait penyebab fenomena dan kejadian, serta menerapkan pengetahuan prosedural pada bidang kajian yang spesifik sesuai dengan bakat dan minatnya untuk memecahkan masalah (C2)."

Jadi, satu dimensi kognitif "menafsirkan" di uraikan berdasarkan dimensi pengetahuan. Pada penelitian ini terdapat tiga dimensi pengetahuan, artinya akan didapatkan 3 komponen KI untuk masing-masing kategori dimensi proses kognitif, sehingga didapatkan tiga komponen KI untuk satu dimensi pengetahuan dan ini juga dilakukan untuk analisis dimensi kognitif selanjutnya. Berdasarkan penyusunan kembali kalimat KI-3, maka dihasilkan 36 kalimat komponen KI-3. Komponen KI-3 yang telah dijabarkan digunakan sebagai acuan dimensi proses kognitif dan dimensi pengetahuan yang harus dikuasai peserta didik.

\section{SIMPULAN}

Berdasarkan penelitian yang telah dilakukan, maka diperoleh kesimpulan, yaitu rumusan KI-3 dianalisis berdasarakan takosomi Bloom revisi dan dikelompokkan sesuai dengan dimensi proses kognitif, dimensi pengetahuan, dan sikap ilmiah sehingga akan diperoleh 3 komponen KI untuk masing-masing kategori dan keseluruhan Komponen KI didapatkan sebanyak 36 komponen KI-3. Komponen KI yang didapatkan dari analisis digunakan sebagai acuan dimensi proses kognitif dan dimensi pengetahuan yang harus dikuasai oleh peserta didik.

\section{REFERENSI}

1. Undang-Undang No 20 Tahun 2003 Tentang Sistem Pendidikan Nasional.

2. Peraturan Pemerintah Republik Indonesia Nomor 32 Tahun 2013 Tentang Perubahan Atas Peraturan Pemerintah Nomor 19 Tahun 2005 Tentang Standar Nasional Pendidikan.

3. Peraturan Menteri Pendidikan dan Kebudayaan Nomor 21 Tahun 2016 Tentang Standar Isi Pendidikan Dasar dan Menengah.

4. Mulyasa. 2006. Kurikulum yang disempurnakan Pengembangan Standar kompetensi dan Kompetensi Dasar. Bandung: PT Remaja Rosdakarya.

5. Peraturan Mentri Pendidikan dan Kebudayaan Republik Indonesia No. 36 Tahun 2018 Tentang
Perubahan Atas Peraturan Menteri dan Kebudayaan Nomor 59 Tahun 2014 Tentang Kurikulum 2013 Sekolah Menengah Atas/ Madrasah Aliyah.

6. Ella, Yulaelawati. 2004. Kurikulum dan Pembelajaran. Jakarta: Pakar Raya.

7. Joseph F. Hair Jr. William C. BlackBarry I. Babin Rolph E. Anderson. 2014. Pearson New International Edition. Printed in The United States of America.

8. Peraturan Menteri Pendidikan dan Kebudayaan Nomor 21 Tentang Standard Isi Pendidikan Dasar dan Menengah.

9. Anderson, L.W., dan Krathwohl, D.R. 2001. A Taxonomy for Learning, Teaching, and Assesing: A Rrvision of Bloom's Taxonomy of Educational Objectives. New York: Addison Wesley Longman, Inc

10. Peraturan Menteri Pendidikan dan Kebudayaan Republik Indonesia No. 37 Tahun 2018 Tentang Kompetensi Inti dan Kompetensi Dasar Pendidikan Dasar dan Menegah. 